\title{
Studi Manajemen Persediaan Just In Time pada Proyek Konstruksi Gedung KPP Menteng
}

\author{
Edward Rizky Ahadian*1 \\ 1Program Studi Teknik Sipil, Fakultas Teknik Unkhair, Ternate \\ *Corresponding authors: e-mail: edo_rizky19@yahoo.com
}

Manuscript received: 15-02-2017 Revision accepted: 18-04-2017

\begin{abstract}
Abstrak
JIT merupakan filosofi produksi yang dikembangkan oleh Toyota Motor dan berhasil membuat industri otomotif dan elektronika Jepang menjadi industri yang mampu bekerja secara efisien dengan mutu keluaran yang baik. Keberhasilan JIT dibidang industri manufaktur telah mendorong industri lainnya termasuk industri konstruksi untuk mengadopsinya. JIT berusaha untuk menghilangkan sumbersumber pemborosan produksi dengan cara menerima jumlah yang tepat dari material dan memproduksinya dalam jumlah yang tepat pada tempat yang tepat dan waktu yang tepat. Studi terhadap metode Just In Time ini dilakukan dengan menggunakan studi kasus terhadap proyek konstruksi pembangunan gedung Kantor Pusat Pajak (KPP) Menteng dengan Kontraktor pelaksana PT. Pembangunan Perumahan (PT.PP). Adapun studi JIT inventory management didasarkan pada tiga aspek kajian, yaitu kebijakan perusahaan dalam pengelolaan persediaan, sistem pemesanan dan penerimaan material. Hasil menunjukkan bahwa telah dilakukan pengelolaan persediaan dengan pendekatan JIT dalam proses produksi proyek KPP Menteng dengan sedikit modifikasi pada prinsip JIT. Beberapa modifikasi tersebut antara lain yaitu adanya buffer sebagai antisipasi terhadap variasi yang ada, hal ini berlawanan dengan prinsip dasar dari JIT yaitu menghilangkan buffer. Upaya-upaya yang dilakukan oleh PT. PP melalui kebijakan maupun sistem pemesanan dan penerimaan material untuk mengurangi pemborosan sejalan dengan metode JIT.
\end{abstract}

Kata kunci: JIT Inventory management, proyek konstruksi gedung, ROP, Safety stock, Lead time

\begin{abstract}
JIT is a production philosophy developed by Toyota Motor and it successes in making the automotive and electronics industries in Jepang to be an efficient industry with good quality output. The success of JIT in manufacturing industry has encouraged other industries, including construction, to adopt it. JIT tries to eliminate production waste sources by receiving an exact number of materials and producing in an exact number at the right place and time. Study on JIT method was conducted using a case study on a construction project of the development of Tax Office (KPP) Menteng building with the contractor of PT. Pembangunan Perumahan (PT.PP). The study of JIT inventory management was based on three study aspects, namely, company policy in inventory management, material ordering system and material receiving system. The result indicated that JIT-approached inventory management had been conducted in the production process of KPP Menteng project with small modification on its principles. Some of the modifications were, such as, the existence of buffer as an anticipation of existing variation, which was in contrast to the basic principle of JIT, which is eliminating buffer. Efforts conducted by PT. PP through its policy or material ordering and receiving systems to reduce waste were in line with the JIT method.
\end{abstract}

Keywords: JIT Inventory management, building construction project, ROP, Safety stock, Lead time 


\section{PENDAHULUAN}

Proyek konstruksi merupakan suatu rangkaian kegiatan yang hanya satu kali dilaksanakan dan umumnya berjangka pendek. Dalam rangkaian kegiatan tersebut, ada suatu proses yang mengolah sumber daya proyek menjadi suatu hasil kegiatan yang berupa bangunan. Proses ini dapat disebut sebagai proses produksi.

Proses produksi dalam proyek konstruksi mempunyai karakteristik tertentu yaitu proses produksi dilakukan dilapangan, dimana pekerja akan datang ke lokasi tempat pelaksanaan tugas dilakukan. Proses produksi ini melibatkan sumber daya yang berupa material. Mengelola aliran material yang tepat berarti tidak terlalu terlambat, dan tidak terlalu dini, jumlahnya sesuai dengan kebutuhan, dan terkirim ke tempat yang memang membutuhkan (Pujawan, 2005). Pengelolaan aliran material ini menimbulkan persediaan.

Inventory atau persediaan merupakan simpanan material yang berupa bahan mentah, barang dalam proses dan barang jadi. Pengendalian terhadap persediaan atau inventory control adalah aktivitas mempertahankan jumlah persediaan pada tingkat yang dikehendaki. Pada produk barang, pengendalian ditekankan pada pengendalian material. Persediaan dapat memiliki berbagai fungsi penting dalam menambah fleksibilitas dari operasi suatu perusahaan. Fungsi dasar persediaan sebenarnya sangat sederhana yaitu meningkatkan profitabilitas perusahaan.Persediaan dalam jumlah banyak akan menyebabkan tingginya biaya untuk penyimpanan dan pembelian bahan atau barang yang bersangkutan, sedangkan kelebihan persediaan juga akan menyebabkan banyaknya dana yang terserap dalam persediaan sehingga tidak efisien. Sebaliknya, bila persediaan terlalu sedikit akan berisiko kekurangan bahan atau barang. Hal ini tentunya akan mengganggu kelancaran proses produksi, selain itu juga biaya pembelian dan biaya persediaan juga semakin besar.

Dalam mengelola persediaan, ada beberapa tool yang digunakan, salah satunya adalah metode Just In Time (JIT). JIT merupakan filosofi produksi yang dikembangkan oleh Toyota Motor dan berhasil membuat industri otomotif dan elektronika Jepang menjadi industri yang mampu bekerja secara efisien dengan mutu keluaran yang baik. Keberhasilan JIT di bidang industri manufaktur telah mendorong industri lainnya termasuk industri konstruksi untuk mengadopsinya.

Perbedaan kondisi pada industri konstruksi dengan industri manufaktur membuat konsep JIT tersebut tidak dapat diterapkan seratus persen. Banyaknya variasi dalam pelaksanaan pekerjaan konstruksi sangat bertolak belakang dengan industri manufaktur, dimana sangat sedikit variasi yang terjadi. Konsep JIT membutuhkan beberapa adaptasi dengan melakukan beberapa modifikasi pada prinsip JIT agar dapat diterapkan dalam proyek konstruksi.

Salah satu elemen JIT adalah manajemen persediaan JIT (JIT inventory management). Permasalahan utama dalam pengelolaan persediaan ini berupa penentuan berapa jumlah material yang dipesan dan kapan dilakukan pemesanan tersebut. Adapun tujuan dari penelitian ini adalah untuk mengetahui bagaimana penerapan metode JIT dalam pengelolaan persediaan material pada pelaksaaan proyek konstruksi bangunan gedung. Penelitian di batasi pada proyek bangunan gedung yang dikerjakan oleh kontraktor BUMN.

\section{METODE PENELITIAN}

Studi terhadap metode Just In Time dalam manajemen persediaan pada pelaksanaan proyek konstruksi gedung dilakukan dengan menggunakan pendekatan studi kasus. Studi kasus 
dilakukan terhadap proyek konstruksi yang dikerjakan oleh kontraktor besar yang telah memiliki banyak pengalaman, sehingga telah mengalami proses pembelajaran yang matang dalam menentukan kebijakan-kebijakan maupun praktik-praktik yang berkenaan dengan pengelolaan persediaan salah satunya yaitu metode JIT.

Adapun karakteristik proyek konstruksi bangunan yang menjadi obyek penelitian ini dilakukan pada proyek yang memiliki tingkat kompleksitas yang tinggi. Berdasarkan pendapat Maylor (2003) dalam susilawati (2005), tingkat kompleksitas suatu proyek dapat dilihat dari tiga hal, yaitu kompleksitas organisasi, kompleksitas sumber daya, dan kompleksitas keteknikan. Proyek konstruksi bangunan yang merupakan salah satu jenis proyek konstruksi yang memiliki variasi didalam pengunaan material dan komponen bangunan, serta penggunaan tingkat spesialisasi yang tinggi, menunjukkan bahwa jenis konstruksi bangunan ini dapat digolongkan sebagai proyek dengan kompleksitas yang tinggi. Proyek yang dijadikan sebagai studi kasus adalah proyek pembangunan gedung kantor pusat pajak (KPP) Menteng yang dikerjakan oleh PT. Perumahan Pembangunan (PT. PP) sebagai kontraktor utama.

Teknik pengumpulan data dilakukan melalui wawancara yang dilakukan pada tingkat manajemen proyek dan pengamatan terhadap proyek yang dikerjakan. Pengamatan di lokasi proyek untuk mendapatkan gambaran terhadap kondisi real di proyek konstruksi. Sedangkan wawancara terhadap pihak yang berkompeten dalam pengelolaan persediaan di tingkat manajemen proyek dilakukan untuk mendapatkan pemahaman sehubungan dengan kebijakan dan pendekatan JIT yang dilakukan. Pihak yang diwawancarai meliputi project manager dan kepala bidang logistik di proyek.

Teknik analisis yang digunakan dalam penelitian ini pada prinsipnya adalah dengan teknik perbandingan. Adapun perbandingan yang dilakukan yaitu membandingkan praktik pengelolaan persediaan material di proyek yang terdiri dari: i) Kebijakan perusahaan dalam pengelolaan persediaan di proyek; ii) Proses atau sistem pemesanan material (meliputi reorder point dan safety stock); dan iii) Sistem penerimaan material terhadap teori dasar JIT dan prinsip dasar JIT inventory management. Ketiga aspek tersebut ditinjau dalam level manajemen di proyek yang bersangkutan. Pada akhirnya, proses analisis ini akan menuju temuan sesuai dengan tujuan yang ingin dicapai.

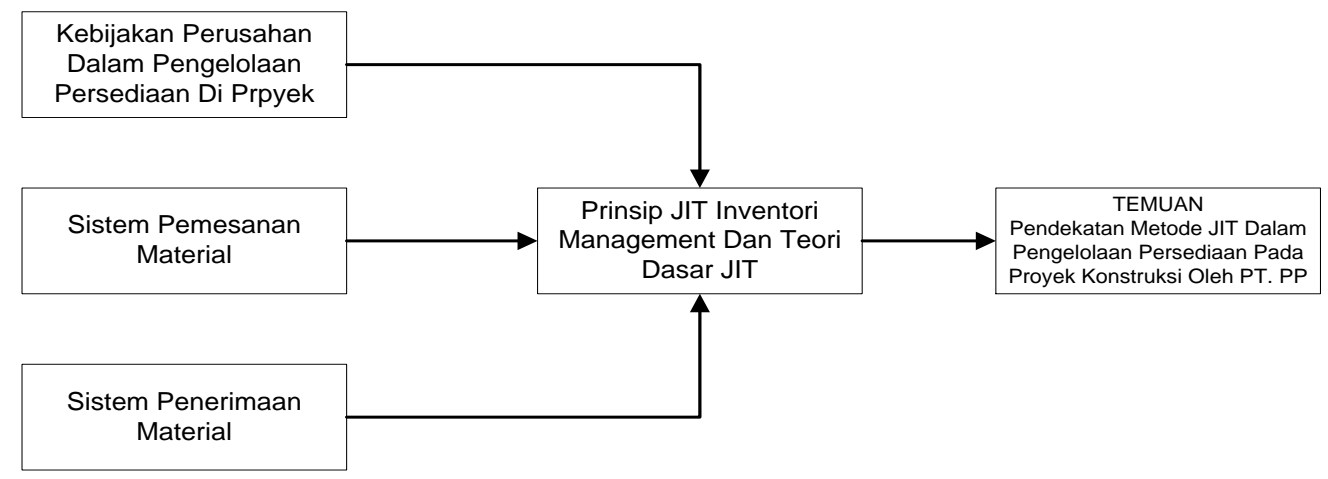

Gambar 1. Kerangka Analisis - Pengelolaan Persediaan JIT 


\section{HASIL DAN PEMBAHASAN}

\section{Studi Kasus Proyek KPP Menteng}

Proyek Pembangunan gedung kantor pusat pajak (KPP) yang berlokasi di daerah Menteng, Jakarta, merupakan proyek pemerintah yang sedang dikerjakan oleh PT. Pembangunan Perumahan sebagai kontraktor utama, PT. Manggilingan Jaya sebagai konsultan manajemen konstruksi dan PT. Gubah Laras sebagai konsultan perencana. Pembangunan gedung ini bertujuan untuk meningkatkan kinerja dari departemen pajak, dimana beberapa kantor pajak yang tersebar di beberapa tempat di Jakarta akan dipusatkan pada gedung ini. Proyek ini dikerjakan secara bertahap yaitu tahap I, II, dan III. Dimana tahap III ini merupakan pekerjaan finishing.

Jenis kontrak yang digunakan pada proyek ini adalah lump sum fixed price. Dan pada tahap III ini, waktu pelaksanaan proyek adalah selama 82 hari dengan masa pemeliharaan selama satu tahun dan dengan nilai kontrak sebesar Rp. 120.001.010.000. Cara pembayaran yang dilakukan untuk proyek ini adalah progress monthly payment, dengan nilai progress minimum $10 \%$.

PT.Pembangunan Perumahan (PT. PP) merupakan salah satu BUMN (dengan komposisi kepemilikan 51 \% oleh pemerintah dan 49 \% oleh karyawan dan Manajemen PT PP) yang bergerak di bidang jasa konstruksi dan telah memperoleh banyak pengetahuan dan pengalaman berharga dari berbagai proyek yang ditanganinya seperti bangunan gedung dan perumahan, bendungan dan irigasi, jalan dan jembatan, pelabuhan dan dermaga, bangunan pembangkit tenaga listrik serta pekerjaan-pekerjaan sipil lainnya.

PT. PP sangat memperhatikan kualitas dalam pekerjaannya, hal ini dapat dilihat dari kebijakan perusahaan dalam kaitannya dengan kualitas, yaitu peduli keinginan dan kepuasan pelanggan, peningkatan kaulitas yang berkesinambungan, pendekatan rekayasa teknik maupun bisnis, pemanfaatan teknologi mutakhir, profesionalisme SDM yang berwawasan global. Dan dengan melakukan pengelolaan yang baik akan berdampak pada peningkatan profitabilitas pada perusahaan.

Dari segi organisasi proyek, PT. PP mengupayakan untuk mempermudah hubungan dengan komponen-komponen penting dalam pelaksanaan proyek. Hal ini dapat dilihat pada gambar 2 dibawah ini.

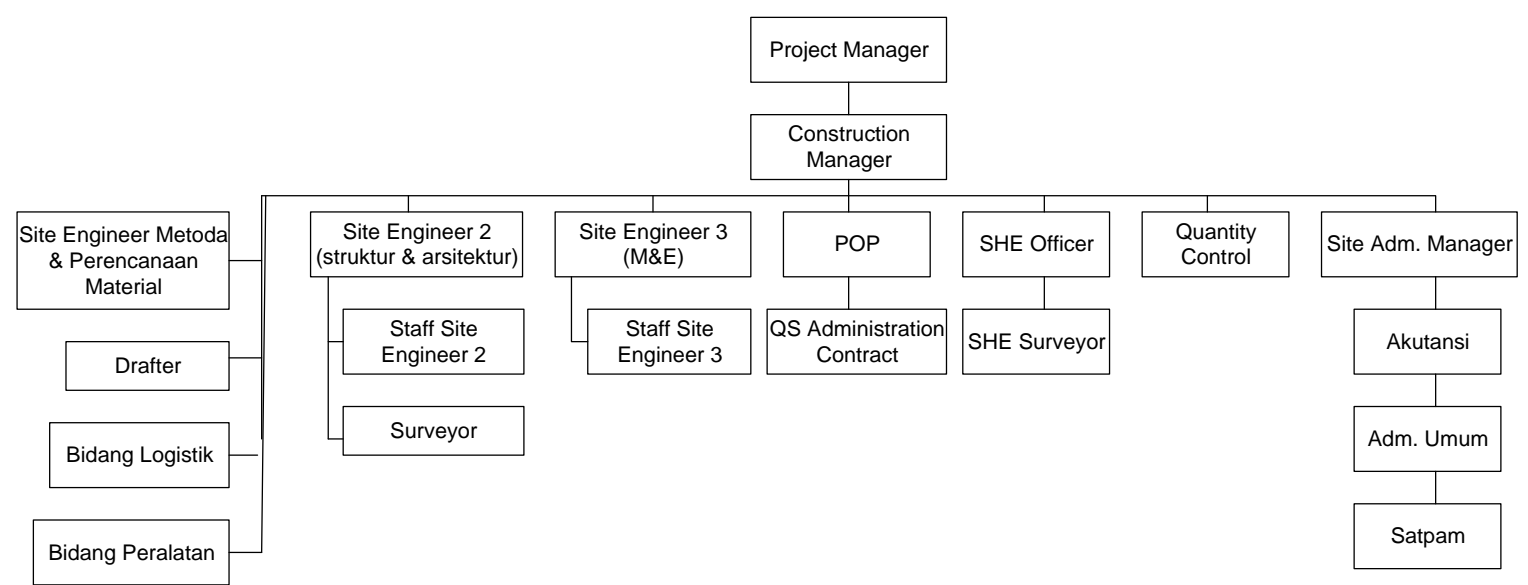

Gambar 2. Struktur Organisasi Proyek 
Sebagai kontraktor yang bersertifikat ISO 9001:2000 (kontraktor pertama Indonesia yang bersertifikat ISO tersebut), PT. PP selalu menyelesaikan pekerjaannya dalam waktu, anggaran dan kualitas yang telah ditentukan.

Mengadopsi ketidakpastian pada kondisi bisnis konstruksi, PT. PP sudah menyesuaikan visinya pada global trend, dengan meningkatkan tradisinya dalam menjalankan bisnisnya secara inovatif, yang berakhir dengan proyek-proyek yang diselesaikan yang sesuai dengan harapan konsumen.

\section{Analisis Pengelolaan Persediaan Pada Proyek Konstruksi Kebijakan Perusahaan Dalam Pengelolaan Persediaan}

Pengelolaan persediaan yang dilakukan oleh pihak manajemen PT. PP mengacu pada kebijakan-kebijakan perusahaan yang ada. Adapun beberapa kebijakan yang terkait dengan pengelolaan persediaan antara lain yaitu :

- Pengelolaan persediaan di proyek menjadi otonomi proyek, diantaranya yaitu menentukan kebutuhan material, menyimpan material, mengendalikan persediaan material, melakukan pembelian material dan mengangkut dan mendistribusikan material

- Material yang diorder sesuai dengan yang diperlukan dan tidak boros serta

- Persediaan yang tersisa mempunyai presentasi-presentasi tertentu tergantung dari item material.

Untuk pembagian kewenangan terhadap pengadaan material antara proyek dan divisi cabang ada beberapa ketentuan yang terkait dengan kebutuhan material. Untuk pengadaan material yang telah memiliki rekanan langsung melalui divisi cabang. Apabila material yang akan digunakan belum memiliki rekanan, maka pengadaan dilakukan oleh pihak manajemen proyek. Hal ini juga dipengaruhi oleh berapa besar jumlah dan biaya material, bila jumlah biaya material yang akan digunakan besar dan dalam jumlah yang banyak, maka akan menjadi tanggung jawab divisi.

Salah satu kebijakan perusahaan dalam pengelolaan persediaan seperti yang telah disebutkan diatas yaitu material yang diorder sesuai dengan yang diperlukan, hal ini sesuai dengan prinsip JIT yaitu menghilangkan sumber-sumber pemborosan produksi dengan cara menerima jumlah yang tepat dari material dan memproduksinya dalam jumlah yang tepat pada tempat yang tepat dan waktu yang tepat. Selain itu, dengan otonomi yang diberikan pada proyek untuk mengelola persediaan memberi kesempatan yang cukup besar bagi pihak manajemen proyek untuk mengelola persediaan dengan sebaik-baiknya terutama dalam mengurangi pemborosan yang terdapat dalam pengelolaan persediaan tersebut.

Metode JIT berusaha untuk mengurangi semua sumber pemborosan dan segala hal yang tidak mempunyai nilai tambah bagi kegiatan produksi. Adapun tujuan dari dilakukan JIT adalah untuk mengurangi jumlah persediaan sehingga perusahaan tidak perlu menyiapkan tempat penyimpanan yang besar, menekan biaya produksi sehingga menambah keuntungan bagi perusahaan, dan meningkatkan kualitas sehingga client puas dengan cara kerja perusahaan. Hal ini sejalan dengan prinsip yang dilakukan dalam JIT. Dari kebijakan perusahaan itu sendiri sudah mengindikasikan bahwa perusahaan berusaha melakukan pendekatan JIT dalam pengelolaan proyeknya. Untuk lebih memaksimalkan penerapan metode JIT yang berdampak dalam antisipasi terhadap pemborosan, ada baiknya PT.PP membuat suatu kebijakan tambahan terhadap proses pemesanan material. Dimana sesuai dengan pendekatan metode JIT yaitu memperpendek waktu pemesanan, dalam hal ini alur dari suatu sistem 
pemesanan. Sebagai contoh, proses pemesanan dapat dilakukan langsung dari proyek ke supplier, sehingga waktu pemesanan dapat diperpendek.

\section{Sistem Pemesanan Material}

Pihak manajemen proyek melakukan pemesanan material sesuai dengan kapan material tersebut akan digunakan dengan memperhitungkan waktu pengiriman material (delivery time) sehingga material tersebut bisa diproduksi tepat waktu dan tidak memerlukan waktu yang lama untuk disimpan. Hal ini bisa menghemat biaya penyimpanan.

Untuk mencapai tujuan tersebut, tim manajemen proyek selalu melakukan update schedule secara mingguan (dua kali seminggu), sehingga dapat diketahui berapa besar kebutuhan material yang akan digunakan dan kapan material tersebut akan diproduksi. Selain itu, pihak manajemen proyek juga selalu melakukan koordinasi secara terpadu dengan vendor-vendor yang terlibat, sehingga vendor-vendor tersebut juga mengetahui kapan material yang dipesan dapat dikirim ke site project. Hubungan koordinasi yang baik antara pihak manajemen proyek dan vendor dapat membantu dalam pengelolaan pengadaan, yang mana hal ini dapat memberikan keuntungan bagi perusahaan.

Dibawah ini merupakan alur pemesanan material yang dilakukan pada proyek KPP. Menteng.

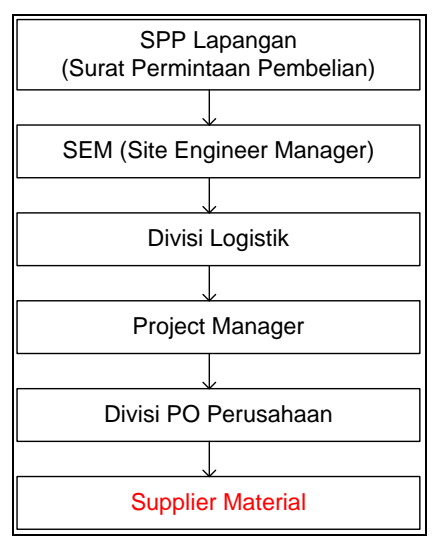

Gambar 3. Alur Sistem Pemesanan Material

Semua material yang ada didalam proyek merupakan otonomi proyek. Dan semua material yang datang merupakan tanggung jawab dari logistik. Oleh karena itu pemesanan dalam jumlah yang lebih atau kurang akan sangat berdampak pada keuntungan proyek. Sebisa mungkin para pihak yang terlibat didalam proyek ini mengurangi pemborosan biaya.

\section{Pemesanan Kembali (Reorder Point)}

Di dalam industri manufaktur, pemesanan material mempunyai siklus yang tetap tetapi hal ini berbeda didalam industri konstruksi, ini bisa dilihat pada proyek KPP Menteng dimana pemesanan material dilakukan sesuai dengan kebutuhan pekerjaan berdasarkan kecepatan pekerjaan (produktivitas kerja). Sehingga material yang datang perminggunya tidak sama. Dan perilaku terhadap pemesanan materialpun tidak sama. Dibawah ini adalah contoh pemesanan material yang dilakukan oleh pihak manajemen proyek KPP Menteng. 
Contoh material A, merupakan material import dengan kebutuhan volume yang besar dan merupakan material finishing. Pemesanan terhadap material A dilakukan sesuai dengan kebutuhan, tetapi mengingat material ini harus diimport dari luar negeri, maka ada beberapa hal yang harus dipertimbangkan seperti berapa lama waktu fabrikasi material A, berapa lama waktu yang dibutuhkan untuk melakukan pengiriman, apa yang akan dilakukan oleh vendor dan tim manajemen proyek ketika material tersebut sampai ke pelabuhan (bea cukai, Pabean) dan angkutan apa yang akan digunakan untuk mengangkut material tersebut dari pelabuhan. Hal-hal tersebut harus dipertimbangkan dengan baik, agar material bisa sampai ke proyek tepat waktu sehingga tidak menghambat pelaksanaan kegiatan. Penjadwalan material A harus tepat, di bawah ini merupakan contoh penjadwalan material A.

\begin{tabular}{lllllllllll}
\hline \multicolumn{1}{c}{ Kegiatan } & \multicolumn{1}{c}{ Minggu } \\
\cline { 2 - 9 } & 1 & 2 & 3 & 4 & 5 & 6 & 7 & 8 & 9 \\
\hline Fabrikasi Material & & & & & & & & & \\
Deliverty Material & & & & & & & & & \\
Custom Clearence (beacukai, Fabian) & & & & & & & & & \\
On site & & & & & & & & \\
\hline
\end{tabular}

Gambar 4. Rencana Material Import

Dari penjadwalan diatas dapat dilihat bahwa material A harus dilakukan pemesanan 2 bulan (8 minggu) sebelum material tersebut digunakan. Akan berbeda halnya bila material yang akan dipesan merupakan material lokal dan tidak diperlukan dilakukan fabrikasi. Ambil contoh material B, yang merupakan material lokal, dengan tingkat kebutuhan yang banyak dan merupakan material finishing.

\begin{tabular}{llllll}
\hline \multicolumn{1}{c}{ Kegiatan } & \multicolumn{4}{c}{ Hari } \\
\cline { 2 - 5 } & 1 & 2 & 3 & 4 & 5 \\
\hline Negosiasi Harga & & & & & \\
Surat Permintaan Pembelian & & & & & \\
Purchase Order & & & & & \\
Schedule & & & & \\
Delivery on site & & & & \\
\hline
\end{tabular}

Gambar 5. Rencana Material Lokal

Dari gambar diatas dapat dilihat bahwa pemesanan terhadap material B dapat dilakukan 3 hari sebelum material tersebut akan digunakan, sehingga material tersebut datang tepat ketika material tersebut akan diproduksi. Oleh karena itu agar pemesanan dapat dilakukan tepat pada waktunya, pihak logistik harus selalu melakukan update schedule.

Untuk menentukan kapan harus mulai membeli, yang harus diperhatikan adalah lead time (tenggang waktu) dari masing-masing bahan. Lead time merupakan waktu yang dibutuhkan sejak pengajuan permohonan pembelian sampai dengan diterimanya material di gudang dan siap untuk dipergunakan. Beberapa faktor yang mempengaruhi lead time dari suatu bahan yaitu jadwal pemakaian bahan yang merujuk pada jadwal pelaksanaan proyek (master schedule), waktu yang diperlukan produsen dalam proses produksi, jarak dan transportasi dari sumber material ke lokasi proyek, formula pemesanan, apakah bertahap atau keseluruhan dan ketersediaan serta kapasitas gudang dan fasilitas penyimpanannya. 
Sedangkan dalam menentukan jumlah bahan yang akan dipesan harus didasarkan pada beberapa pertimbangan antara lain yaitu kuantitas persediaan yang paling efisien adalah dengan menjamin kontinuitas produksi di lapangan. Penumpukan material yang terlalu lama beraarti ada dana yang mengendap dan tidak produktif, tidak menghasilkan pendapatan bahkan bisa menambah biaya proyek karena adanya tambahan biaya inventory.

\section{Persediaan Pengaman (Safety Stock)}

Safety stock merupakan persediaan tambahan yang diadakan untuk melindungi atau menjaga kemungkinan terjadinya kekurangan bahan (stock out). Akan tetapi pada proyek ini, pihak manajemen proyek tidak memperhitungkan safety stock dalam pengelolaan persediaannya. Persediaan pengaman tersebut cenderung diartikan sebagai waste dengan kisaran sebesar 3\% untuk material selain besi dan $15 \%$ untuk material besi. Prinsip ini sesuai dengan sikap pengelolaan persediaan dalam JIT yaitu persediaan adalah pemborosan dan salah satu prinsip JIT inventory management yaitu seek zero inventory. Tidak tersedianya persediaan pengaman dapat meningkatkan biaya proyek dikarenakan kurangnya antisipasi terhadap adanya ketidakpastian yang tinggi yang ada didalam proyek konstruksi. Dengan variasi yang ada seperti tingkat ketidakpastian yang tinggi, maka alangkah baiknya ada persediaan pengaman (safety stock) untuk mengantisipasi keadaan terburuk keterlambatan kedatangan material yang mana akan berdampak pada keterlambatan proyek dan pada akhirnya akan terjadi penambahan biaya proyek, yang mana semua hal tersebut merupakan pemborosan.

\section{Sistem Penerimaan Material}

Setelah material sampai ke site project ada beberapa hal yang dilakukan oleh pihak logistik yaitu seperti yang terlihat pada gambar 6 di bawah ini :

Proses Kedatangan Material

di gudang penerimaan $\quad \rightarrow \quad$ Ketentuan penyimpanan material

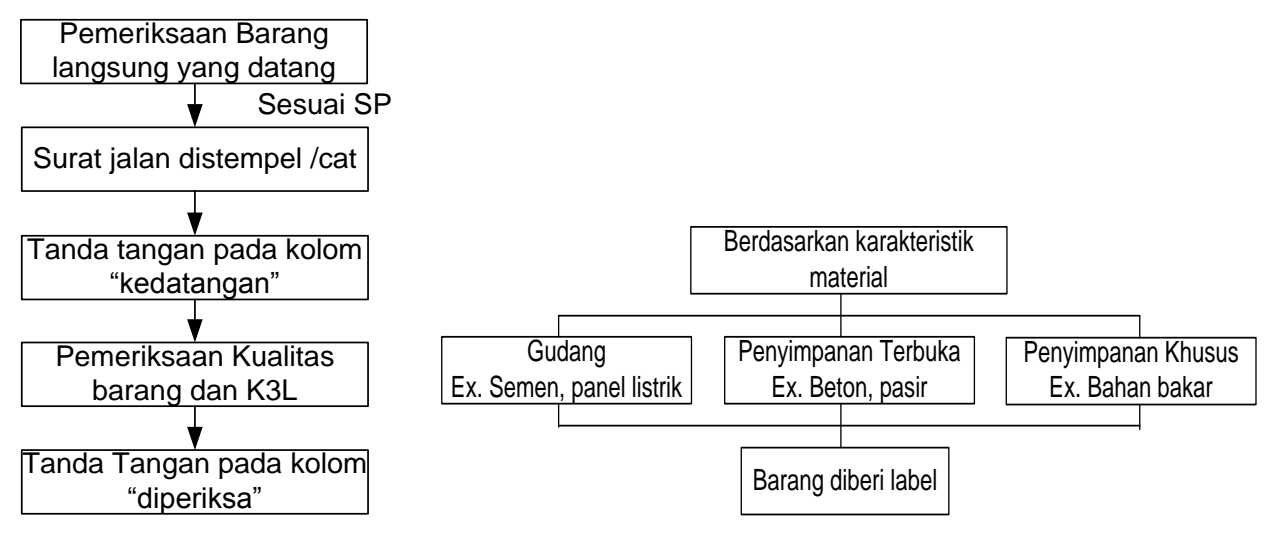

Gambar 6. Alur Sistem Penerimaan Dan Peyimpanan Material

Dari gambar diatas dapat dilihat bahwa tim logistik KPP Menteng sudah melakukan pengelolaan material dengan baik dengan membeda-bedakan tempat penyimpanan material tergantung dari karakteristik jenis material, yaitu gudang (untuk semen, panel listrik), penyimpanan terbuka seperti pasir, beton, dan penyimpanan khusus seperti bahan peledak dan bahan bakar. Barang tersebut diberi label sebagai petunjuk tempat penyimpanannya. Material yang telah diterima tersebut kemudian dicatat dalam kartu stock. 
Didalam teori JIT, dikenal istilah kanban (kartu kendali). Kanban tersebut berisi rangkaian isyarat yang mengendalikan proses yang ada. Tujuan sistem kanban adalah memberikan tanda-tanda kebutuhan material yang lebih banyak dan meyakinkan bahwa material tersebut akan diproduksi tepat pada jadwal waktu dalam rangka mendukung produksi berikutnya. Kanban umumnya merupakan suatu isyarat visual sederhana, seperti untuk menunjukkan tidak tersedianya atau hanya tersedia sebagian dari suatu komponen atau subkomponen yang dibutuhkan pada rak penyimpanan.

Tetapi pada proyek konstruksi (KPP Menteng), sistem kanban ini tidak digunakan. Pengontrolan material lebih ditekankan pada update kartu stock perhari. Kartu stock akan selalu diupdate setiap hari oleh pihak logistik, ini untuk melihat berapa jumlah material yang sudah digunakan dan yang tersisa untuk menentukan kapan material selanjutnya dipesan. Tidak dipakainya sistem kanban ini karena kondisi ataupun proses produksi yang berbeda pada proyek konstruksi dengan manufakturembahasan terhadap hasil penelitian dan pengujian yang diperoleh disajikan dalam bentuk uraian teoritik, baik secara kualitatif maupun kuantitatif.

\section{SIMPULAN}

Perbedaan kondisi pada industri konstruksi dengan industri manufaktur membuat konsep JIT tersebut tidak dapat diterapkan seratus persen. Banyaknya variasi dalam pelaksanaan pekerjaan konstruksi sangat bertolak belakang dengan industri manufaktur, dimana sangat sedikit variasi yang terjadi. Konsep JIT membutuhkan beberapa adaptasi dengan melakukan beberapa modifikasi pada prinsip JIT agar dapat diterapkan dalam proyek konstruksi. Beberapa modifikasi tersebut antara lain yaitu adanya buffer sebagai antisipasi terhadap variasi yang ada, hal ini berlawanan dengan prinsip dasar dari JIT yaitu menghilangkan buffer.

PT. PP sudah menunjukkan bahwa mereka telah menerapkan pendekatan JIT dalam dalam proses produksi pada pelaksanaan proyek KPP Menteng ini. Upaya-upaya yang dilakukan oleh PT. PP melalui kebijakan maupun sistem pemesanan dan penerimaan material untuk mengurangi pemborosan sejalan dengan metode JIT. Dalam pengelolaan persediaan pada proyek ini, teridentifikasi beberapa hal yang terkait dengan prinsip-prinsip maupun tujuan dari metode JIT itu sendiri.

Sistem kanban sebagai bagian dari metode JIT tidak digunakan dalam pengelolaan persediaan di proyek karena adanya perbedaan proses produksi konstruksi dengan manufaktur, dimana pada industry konstruksi, lokasi proses produksi tetap dan tenaga kerjanya yang bergerak menuju lokasi proses produksi. Sedangkan pada manufaktur berlaku sebaliknya.

Permasalahan utama dalam pengelolaan persediaan adalah menentukan kapan pemesanan dilakukan dan berapa jumlah material yang dipesan. Dalam menentukan kapan harus melakukan pemesanan, ada beberapa hal yang harus diperhatikan, salah satunya yaitu lead time (tenggang waktu) dari masing-masing bahan. Beberapa faktor yang mempengaruhi lead time dari suatu bahan yaitu jadwal pemakaian bahan yang merujuk pada jadwal pelaksanaan proyek (master schedule), waktu yang diperlukan produsen dalam proses produksi, jarak dan transportasi dari sumber material ke lokasi proyek, formula pemesanan (apakah bertahap atau keseluruhan), ketersediaan serta kapasitas gudang dan fasilitas penyimpanannya. Sedangkan untuk menentukan jumlah material yang dipesan harus berdasarkan pada beberapa pertimbangan, antara lain yaitu kuantitas persediaan yang paling efisien (dengan 
menjamin kontinuitas produksi di lapangan). Faktor lain yang ikut mempengaruhi adalah ketersediaan fasilitas penyimpanan dan lokasi proyek (terkait penentuan kebijakan pengadaaan bahan).

\section{SARAN}

Pada dasarnya dengan pengalaman yang dimiliki disertai dengan kebijakan perusahaan dalam hal kualitas, PT. PP tentunya telah mengupayakan berbagai cara untuk menjadi lebih baik. Adapun beberapa saran yang dapat diberikan untuk penelitian selanjutnya diantaranya yaitu perlu adanya perbandingan beberapa proyek sejenis dan memperbanyak variabel penilaian untuk mendapatkan gambaran yang lebih jelas terkait dengan penerapan manajemen persediaan JIT di proyek konstruksi gedung.

\section{DAFTAR PUSTAKA}

Indrajit, Ricardus Eko \& Djokopranoto, Richardus., 2003, Manajemen Persediaan : Barang Umum dan Suku Cadang untuk Keperluan Pemeliharaan, Perbaikan dan Operasi, Grasindo : Jakarta

Pujawan, I. Nyoman., 2005, Supply Chain Management, Guna Widya : Surabaya

Schniederjans, Marc J., 1993, Topics In Just-In-Time Managemenet, Allyn And Bacon: Massachusetts

Schroeder, G. Roger., 2007, Operation Management : Contemporary Concepts And Cases Third Edition, International Edition, McGraw-Hill: New York

Subagyo, Pangestu., 2000, Manajemen Operasi Edisi Pertama, BPFE: Yogyakarta

Sumayang, Lalu., 2003, Dasar-Dasar Manajemen Produksi \& Operasi, Salemba Empat: Jakarta

Susilawati, 2005., Studi Supply Chain Konstruksi Pada Proyek Konstruksi Bangunan Gedung, Tesis, Program Pasca Sarjana Teknik Sipil, Institut Teknologi Bandung, Bandung 